PRZEMYSŁAW NEHRING

Nicolaus Copernicus University, Toruń

\title{
THE AUTHORITY OF SENECA IN EARLY CHRISTIAN ARGUMENTATION
}

ABSTRACT. Nehring Przemysław, The Authority of Seneca in the Early Christian Argumentation.

The paper deals with the authority of Seneca as employed by the eminent early Christian writers in their apologetic as well as polemical works.

Keywords: Seneca; Tertullian; Lactantius; Jerome; Augustine; rhetoric; argumentation.

The fact that both Augustine and Jerome, the most distinguished Latin Church writers of late $4^{\text {th }}$ and early $5^{\text {th }}$ centuries, believed in - or at least allowed for - the authenticity of the apocryphal correspondence between Seneca and St. Paul, ${ }^{1}$ undoubtedly testifies to the fact that this Roman writer and philosopher was treated exceptionally in the Latin Christian world. The origins of the legend of a natural proximity of his views with the Church doctrine only just taking shape can be traced back to the earliest Latin Christian literature, i.e. in Tertullian's works, whereas its strengthening can be seen in statements of convert professor of rhetoric Lactantius, active in the epoch of the nascent power of the institutional Church during the reign of Constantine, and its vitality is confirmed in opinions voiced by Jerome and Augustine, who wrote and were active in the golden period of the patristic epoch, namely at the turn of $4^{\text {th }}$ and $5^{\text {th }}$ centuries. Trivial in its obviousness, and a generally repeated observation that Christian ethics owed a lot to the moral philosophy of the Stoics, it could be a good explanation why the most renowned Latin writer

\footnotetext{
${ }^{1}$ See Hier. De viris illustr. 12: "Lucius Annaeus Seneca Cordubensis, Sotionis stoici discipulus et patruus Lucani poetae, continentissimae vitae fuit, quem non ponerem in catalogo sanctorum nisi me illae epistulae provocarent, quae leguntur a plurimis Pauli ad Senecam et Senecae ad Paulum. In quibus, cum esset Neronis magister et illius temporis potentissimus, optare se dicit eius esse loci apud suos, cuius sit Paulus inter Christianos. Hic, ante biennium quam Petrus et Paulus martyrio coronarentur, a Nerone interfectus est..."; Aug. Ep. 153, 5: "merito ait Seneca, qui temporibus apostolorum fuit, cuius etiam quaedam ad Paulum apostolum leguntur epistulae: omnes odit, qui malos odit." For more on apocryphal correspondence, see: Fürst 2006, 3-85, there also see wide bibliography concerning this subject, 201-207.
} 
associated with this school was invoked with such respect by the Church authors of the early centuries. Thanks to his brilliant and very attractive statements in both rhetorical and literary terms, already Quintilian, who was not particularly friendly to him - called him "egregius tamen vitiorum insectator" (Quint. X $1,129)$, and this opinion was repeated almost verbatim by Lactantius, who wrote about Seneca: "morum vitiorumque publicorum et descriptor verissimus et accusator acerrimus fuit" (Div. inst. V 9,19). Seneca's name appears in the Christian literature in theological contexts equally often as in moral ones. Thus, his authority or significance went beyond the sphere of ethics, or it was to play a particularly persuasive role, not necessarily for Christian readers of these works. Analysis of individual cases conducted in chronological order should bring us closer to specific conclusions in this matter.

\section{TERTULLIAN (CA. 160 - CA. 220)}

Tertullian, despite or perhaps just because of the fact that he was a highly educated rhetor, ${ }^{2}$ attempted to use the strongest possible antitheses to present the Greco-Roman philosophy and the Christian world. This author writing in North Africa at the turn of the $2^{\text {nd }}$ and $3^{\text {rd }}$ centuries definitely distanced himself from the classical philosophical tradition, and considered the Christian faith as true wisdom. ${ }^{3}$ Perhaps the most often quoted sentence from his writings - "Quid Athenis et Hierosolymis"? (Adv. Herm. 7) - perfectly illustrates this dichotomy. In fact, he too drew heavily on the earlier philosophical tradition, not only the Stoic one, but he even allowed for the ascribing of philosophy to a role of peculiar propaedeutic in getting to know God, on the other hand, however, in caring for the integrity of Christian teaching, he ostentatiously distanced himself from the views of various pagan thinkers. ${ }^{4}$ His apologetic writings, particularly his famous Apologeticus - are full of derogatory statements for individual philosophical schools, including that of the Stoics, and the pagan culture in general. ${ }^{5} \mathrm{He}$ calls Greek philosophers outright "patriarchs of all heresies." ${ }^{\prime 6}$ Tertullian's personal references to Seneca should be particularly perceived against this backdrop. In my opinion, two of them deserve to be addressed separately. The first one comes from Apologeticus, one of his earliest works (written around 197), and it appeared at the end of a tirade of arguments used by Tertullian to prove absurd

\footnotetext{
${ }^{2}$ For Tertullian's rhetorical education and the role of rhetoric not only in the formation of argumentation, but his views in general, see a still valid monograph Sider 1971

${ }^{3}$ See Tert. Ad nation. II 2,4; De anima 1,6.

${ }^{4}$ For Tertulian's complicated attitude towards the classical tradition, see Fredouille 1972, $337-357$.

${ }^{5}$ See e.g. Tert. Apolog. 46,18

${ }^{6} A d v$. Herm. 8,3; De praescr. VII 3,5; also, compare Adv. Marc. I 13,3.
} 
of the nature of the pagans' hostile attitude to Christianity. Hence, in turning directly to pagan recipients of his work, he wrote:

O impiae voces, o sacrilega convicia! Infrendite, inspumate! Iidem estis, qui Senecam aliquem pluribus et amarioribus de vestra superstitione perorantem probetis (Apol. 12,26).

The overtone of this sentence is clear - since the pagans have nothing against Seneca, who rebukes their superstitions more abundantly and acutely than Christians, then they should not look sternly at the followers of Christ. Arguably, Tertullian refers to Seneca's De superstitione $e^{7}$ known to us only in fragments. In this argument structure a maiore ad minus, Seneca was presented as one who considered pagan religion as superstition, but surely also as a pagan, and even an unquestionable authority in that cultural circle. Thus, invoking his authority is to effectively convince the pagans for whom Apologeticus was meant in the first place that they are wrong. Tertullian's ostentatious distancing from Seneca is expressed in attribute aliquis - "a certain Seneca."

Another interesting quote in which the philosopher's name appeared comes from treatise De anima, written by Tertullian around 210. This work appeared in the period of the African writer's doctrinal polemics. In referring in it to a controversy with Hermogenes, in which one of the trouble spots was the origin and the nature of the soul, Tertullian argued, following the Stoics and against Plato's advocates, that it is a physical being. In convincing, among others, about the fact that any faculties of the soul constitute parts of its substance, and that they are present in it from the time a baby is born, and develop as it grows up, he quoted a sentence from Seneca's treatise De beneficiis 4,6,6 illustrating this thesis:

Sicut et Seneca saepe noster: insita sunt nobis omnium artium et aetatum semina, magisterque ex occulto deus producit ingenia, ex seminibus scilicet insitis et occultis per infantiam, quae sunt et intellectus (De anima 20,3).

Describing the philosopher with a possessive adjective noster is symptomatic here. The adverb saepe does not allow us to treat this adjective as a simple indication of Seneca's "Latinity", and the consecutive quotation from the - let us add, extant - work of the philosopher does not provide the basis to see in this sentence a rhetorical order and connect this adverb with the conjectural verbum dicendi implying that Seneca would allegedly often quote the thought mentioned above. Hence, we should, as is often assumed in the subject literature, understand the expression "Seneca saepe noster" as a reference to the views advocated by

\footnotetext{
${ }^{7}$ For more on this writing of Seneca, well known in Christian circles, its content and fragments preserved in Augustine, and without quoting the source in Minucius Felix, see Lausberg 1970, $197-227$.
} 
him that supposedly were often close to the Christian thought. The possessive adjective noster carries almost always the meaning "Christian" in Tertullian. The African apologist, as in the previous example, invoked Seneca's authority in his argumentation, but this time he was concerned with presenting him as an almost Christian thinker, whose views could be treated by Christians as their own. This "Christianisation" of Seneca finds its deep justification here in the argumentative strategy present in De anima. A discussion included in this work regarded an intrinsically Christian dispute, so it was meant for the Christians themselves, and not pagans, as in Apologeticus. To avoid an allegation that in this theological matter, which the nature of the soul undoubtedly was, he considers exclusively the views of various pagan philosophical schools, by rejecting some and accepting others, he presented Seneca not only as a Stoic, but also as the thinker closest to Christianity.

\section{LACTANTIUS (CA. 250 - CA. 330)}

The most personal references to Seneca can be found in another Christian author also from Northern Africa, Lactantius. ${ }^{9}$ This outstanding apologist, theologian, and professor of rhetoric, who became known to posterity as Cicero Christianus, was almost an entire century younger than Tertullian. His attitude to Seneca, full of admiration, can be best testified to by saying that Seneca could even have become Christian if only somebody had shown him the way to "true knowledge", and obviously, if he rejected the teachings of his philosophical masters Zeno and Sotion. ${ }^{10}$ This opinion of the author of Divinae institutiones clearly shows that he was unaware of the so-called correspondence between Seneca and Saint Paul, which - although it is only argumentum ex silentio - is generally believed by the scholars to be decisive in determining the terminus post quem for creating this apocryphal work after the year $313 .{ }^{11}$ However, it is not this closeness to Christian views that is the basis for Lactantius' treatment

${ }^{8}$ J. H. Waszink, outstanding publisher and scholar of Tertullian's treatise De anima, in his German translation of this fragment leaves no doubts as to its understanding: "So sagt auch Seneca, der oft unsere Ansichten teilt", see Waszink 1980, 93; also see a comment to this fragment therein: 255 , footnote 150 .

${ }^{9}$ See Trillitzsch 1971, 130

${ }^{10}$ Lact. Div. inst. VI 24,14: "[...] potuit esse verus Dei cultor, si quis illi monstrasset, et contempsisset profecto Zenonem et magistrum suum Sotionem, si verae sapientiae ducem nactus esset."

${ }^{11}$ For dating of Divinae institutiones see Ingremeau 2006, 11; for dating the apocryphal correspondence between St. Paul and Seneca based on the above quoted sentences by Lactantius, see, among others, Trillitzsch, 1965, 53. Attempts to determine a more precise date of creating this collection have not produced satisfactory results to date. Certainly, it was known to Jerome, when in 392/393 he was writing his De viris illustribus; stylistic analysis of these letters seems to 
of Seneca as an authority whose invoking may have persuasive significance. It is the glory of the philosopher, the brightest of all the Stoics. He called him like that twice in Divinae institutiones, ${ }^{12}$ his most important work, the first compendium of the Christian doctrine meant at least equally for Christian recipients, but also for educated pagans who undermined the value of the new religion. ${ }^{13}$ Lactantius himself converted quite late, and even after this landmark act of his life, he remained an active teacher of rhetoric, and was more prone to base his argumentation on the philosophical tradition than quotations from the Holy Scripture. ${ }^{14}$

Although the Roman author whom Lactantius invokes and admires most is Cicero, whom he values as a distinguished philosopher, also Seneca has a key role to play. Almost every quotation or personal reference to Seneca's specific statement included in Divinae institutiones is preceded by their author by an evaluative adverb. So, Seneca says, in Lactantius' account, verum (Div. inst. I 7,5), recte (Div. inst. II 2,14), merito (Div. inst. II 4,14), melius (Div. inst. II 8,23 ), or at least non illepide, i.e. not without charm (Div. inst. I 16,10). And even if this Christian author criticises his definition of philosophy, he is lenient in approaching this error which, according to him, even Cicero could not avoid. ${ }^{15}$ Therefore, not only does Lactantius recognise Seneca as a sage reaching beyond all the Stoics, but also treats the views of Seneca he quotes as right from his own, after all Christian, point of view. In appreciating philosopher's ideas, he even goes so far that, while considering in book five of his work the issue of theodicy, he makes reference to Seneca's work De providentia, and his statement quoted further on as virtually one inspired by God. ${ }^{16}$ However, as proved by

indicate the second half of the $4^{\text {th }}$ century or perhaps even its last quarter, as the most probable time of their creation, see Fürst 2006, 6-10.

${ }^{12}$ See Lact. Div. inst. I 5,26: "Annaeus quoque Seneca, ex Romanis vel acerrimus Stoicus"; ibid. 2,8,23: "Seneca omnium Stoicorum acutissimus."

${ }^{13}$ The fact that Lactantius was even more effective in dealing with the argumentation of Christianity's opponents than strengthening Christians in the faith can be best attested by the opinion given by Jerome, see Hier. ep. 58,10: "Lactantius, quasi quidam fluvius eloquaentiae Tullianae, utinam tam nostra adfirmare potuisset, quam facile aliena destruxit!"

${ }^{14}$ Although R. Pichon's thesis (Pichon 1902, see in particular p. 217) generally accepted for almost the entire $20^{\text {th }}$ century, that Lactantius knew the Bible solely from Cyprian's work, $\mathrm{Ad}$ Quirinum testimonia adversus Iudaeos, was successfully undermined, see first of all Monat 1982, the argumentative function of biblical quotations and allusions in the work of this Constantine-era apologist is incomparably smaller than in other $4^{\text {th }}$-century Christian authors.

${ }^{15}$ Lact. Div. inst. III 15,1: "Eodem ductus errore Seneca - quis enim veram viam teneret errante Cicerone? - philosophia inquit nihil aliud est quam recta ratio vivendi vel honeste vivendi scientia vel ars rectae vitae."

${ }^{16}$ Lact. Div. inst. V 22,11: "si quis autem volet scire plenius cur malos et iniustos deus potentes beatos divites fieri sinat, pios contra humiles miseros inopes esse patiatur, sumat eum Senecae librum cui titulus est 'Quare bonis viris multa mala accidant, cum sit providentia', in quo ille multa non plane imperitia saeculari, sed sapienter ac paene divinitus elocutus est.” 
a scrupulous comparative investigation of references to the Seneca's extant works in Lactantius' writings, the Christian apologist approaches the words of the "brightest Stoic" with much latitude. Not only does he quote sentences which couldn't have an argumentative function as understood in their original context, but he also resorts to consciously "reworking" them to achieve proper persuasive effect. ${ }^{17}$

Personal references to Seneca appear in 6 out of 7 books of Divinae institutiones, and they are supposed to support the conviction of the validity of the theses included in them within the broadest scope possible - from moral issues, to defence of Christian monotheism and criticism of pagan idolatry. Among the philosopher's works that are quoted or just mentioned by title, there appear the following: De immatura morte, Exhortationes, Libri moralis philosophiae, De providentia. Only the last writing has survived until the present, but in its case the philosopher's idea invoked in Divinae institutiones comes from the fragment of the dialogue not extant in the manuscripts. For the other works from this list, Lactantius' account is the basic source of fragments. What's interesting is that, none of the other quotations which the Christian apologist connects with Seneca in this work - not giving the title of the work from which this reference comes can be found in the philosopher's writings preserved until today either.

Apart from Divinae institutiones, personal references to Seneca appear in two more writings of Lactantius. Namely, he invoked the philosopher's dialogue De ira Dei, incompletely extant to this day, in which he opposed the Stoics by proving that God's punishing justice and related emotionality (anger) is an obvious thing. He invokes here the authority of the philosopher as a doxologist who catalogued the definitions of anger formulated by previous thinkers, and himself favouring the Aristotelian understanding of this feeling. ${ }^{18}$ From a whole range of quotations referred to in this context by Lactantius, only one sentence can be found in the dialogue text preserved until today, i.e.:

Aristotelis definitio non multum a nostra abest. Ait enim iram esse cupiditatem doloris reponendi (Sen. De ira 1:3:3).

In Epitome Divinarum institutionum, a peculiar excerpt that Lactantius personally made from his main work and dedicated it to "brother Pendandius", Seneca is mentioned beside Cicero, as representatives of Roman philosophers

${ }^{17}$ See C. Lo Cicero 1991, 1237-1261.

${ }^{18}$ De ira Dei 17,13: "Nescisse autem philosophos quae ratio esset irae apparet ex finitionibus eorum, quas Seneca enumeravit in libris quos de ira conposuit: «Ira est, inquit, cupiditas ulciscendae iniuriae aut, ut ait Posidonius, cupiditas puniendi eius a quo te inique putes laesum»; «Quidam ita finierunt: ira est incitatio animi ad nocendum ei qui aut nocuit aut nocere uoluit»; "Aristotelis definitio non multum a nostra abest. Ait enim iram esse cupiditatem doloris reponendi»." For the argumentative function of this quotation, see Lausberg 1970, 35. 
who, like many Greek philosophers (Thales, Pythagoras, Anaximenes, and the Stoics Cleanthes and Zeno) understood the essence of supreme deity similarly to Christian theology. ${ }^{19}$ In this reference made to Seneca, we can see, as was earlier in Tertullian, a possessive adjective noster (Epitome 4,3: “...vel nostrorum Seneca stoicos secutus et ipse Tullius praedicaverint...”), but here it carries a different meaning than in Tertullian's Apologeticus. It is only to denote Seneca's and Cicero's affiliation with Latin culture, and not Christianise their views. ${ }^{20}$

\section{JEROME (CA. 340 - CA. 420)}

By placing Seneca as St Paul's correspondent in his catalogue of Christian writers, Jerome undoubtedly contributed to authenticating in subsequent centuries the legend of the philosopher's at least close relations with Christianity. Briefly characterising him in this note, he wrote that Seneca was a Stoic, a teacher of Nero, by whom he was killed, and he lived in a very abstinent way. ${ }^{21}$ Jerome invoked his authority only in one work, a polemic treatise Adversus Iovinianum written shortly after De viris illustribus. ${ }^{22}$ In it, he passionately attacked a Roman monk Iouinianus who in the last decade of the $4^{\text {th }}$ century questioned the particular value of ascetic practices, in the first instance sexual continence, and consequently, the superiority of the virtue of virginity over the good of marriage, spread in official Church circles. ${ }^{23}$ In this work, Jerome invokes Seneca as the author of De matrimonio, which has not survived until the present. Also he-like Tertullian and Lactantius earlier - defined the philosopher using the attribute noster. An analogous context in which this expression appears, and thus a reference to distinguished Greek philosophers, in this case Aristotle and Plutarch, and then placing beside them Latin Seneca, makes us interpret the meaning of this attribute the same way as in Lactantius' Epitome, i.e. as associating Seneca with the Roman tradition. The fact that it is not an attempt to "Christianise" the philosopher is attested to by a broader background against which Seneca appears here, as well as quotations from his work. In this part of the treatise, Jerome refers to the views of various pagan philosophers focussed on the problem

${ }^{19}$ Epitome 4,3: "longum est recensere quae de summo deo vel Thales vel Pythagoras et Anaximenes antea vel postmodum Stoici, Cleanthes et Chrysippus et Zenon, vel nostrorum Seneca Stoicos secutus et ipse Tullius praedicaverint, cum hi omnes et quid sit deus definire temptaverint et ab eo solo regi mundum adfirmaverint nec ulli subiectum esse naturae, cum ab ipso sit omnis natura generata."

${ }^{20}$ See Lausberg 1970, 18.

${ }^{21}$ See footnote 1 above.

${ }^{22}$ This time coincidence - both works were created in Bethlehem in the early $90 \mathrm{~s}$ of the $4^{\text {th }}$ century - is pointed out by L. Takács in his article Takács 2000, 325.

${ }^{23}$ For the controversy and the role Jerome played in it, see: Hunter 2007, Nehring 2007, 189 200. 
of whether a philosopher should marry. To this question, already present on the level of school progymnasmatic theses, answered such thinkers - let us add, rather negatively - as Theophrastus, Aristotle, Plutarch and Seneca. The author of the treatise Adversus Iovinianum admits that he drew many arguments on the superiority of celibacy over marriage from their writings, and Seneca receives a special treatment here, as Jerome quoted his statements directly. The views of the Stoics were ambiguous in this matter. On the one side, resisting emotions had, according to their teachings, a fundamental meaning on the road to virtue, and thus preserving abstinence, also a sexual one, was a value, and on the other side, they appreciated marriage as an institution ensuring the continuity of existence of not only families, but also the entire state. ${ }^{24}$ By broadly referring to Seneca's treatise devoted directly to marriage, Jerome took the wind out of the sails of his adversaries in the dispute he engaged himself in. Unambiguous presentation of the philosopher, distinguished representative of Stoicism, and at the same time a man living very abstemiously, a proponent of the thesis of the superiority of celibacy over marriage, weakened the voices of those who in the common dissemination of ascetic ideals saw a threat to traditional social order, and could seek support for their position also in the teachings of the Stoics.

\section{AUGUSTINE (354-430)}

The last of the early Christian authors who made personal references to Seneca was Augustine himself. He too, like Jerome (or perhaps getting this information directly from Jerome?) was at least aware of the apocryphal correspondence between St. Paul and Seneca, and at least did not rule out its authenticity. ${ }^{25}$ The attitude of the bishop of Hippo to the philosopher is not at all unambiguous as it was in the case of previous Christian authors. No evaluative judgements appear in his writings that could corroborate the thesis of the great respect he had for him. ${ }^{26}$ Augustine makes abundant and personal references to Seneca in book VI of his great apologetic work De civitate Dei. ${ }^{27}$ After the first five books in which

${ }^{24}$ For more on this, see: Schofield 1991, 119-127.

${ }^{25}$ See footnote 1 above.

${ }^{26}$ Cf. Hagendahl 1967, 676-677.

${ }^{27}$ Aug. De civ. VI 10-11: "libertas sane, quae huic [Varroni] defuit, ne istam urbanam theologiam theatricae simillimam aperte sicut illam reprehendere auderet, Annaeo Senecae, quem nonnullis indiciis invenimus apostolorum nostrorum claruisse temporibus, non quidem ex toto, verum ex aliqua parte non defuit. Adfuit enim scribenti, viventi defuit. Nam in eo libro, quem contra superstitiones condidit, multo copiosius atque vehementius reprehendit ipse civilem istam et urbanam theologiam quam Varro theatricam atque fabulosam. [...] unde in his sacris civilis theologiae has partes potius elegit Seneca sapienti, ut eas in animi religione non habeat, sed in actibus fingat. [...] hic [Seneca] inter alias ciuilis theologiae superstitiones reprehendit etiam sacramenta Iudaeorum et maxime sabbata, inutiliter eos facere adfirmans, quod per illos singulos 
he disposed of the views of those who claimed that performing traditional cults can bring any benefit in temporal life, in the subsequent, second part of his work (books VI-XI) he proved that worship of deities has no relation to man's eternal life. Thus, Augustine rejected a pagan theology in a comprehensive manner, and he did it systematically and, apparently, effectively towards those who accused Christians of drawing people away from traditional cults, and thereby inviting disaster to Rome. For he quoted and then challenged the threefold understanding of the matters of God that were put forth by the unquestioned Roman authority in these matters, i.e. Varro. So, the pagan theology could not resist criticism in its mythological, natural or social dimension. The authority of Seneca, who did not agree with Varro, was something Augustine needed to prove that not only from the Christian point of view, but also the reasonable pagan philosophical point of view, no pagan theological concept defends itself. The very title of Seneca's work quoted widely herein, given as "against superstitions", referred to earlier by Tertullian, clearly schematised the pagan religion. What is interesting is that the bishop of Hippo invoked this treatise as well quoting the philosopher's critical statement on the religiousness of the Jews by giving us to understand that Seneca could perfectly distinguish them from Christians. What's more, he even allowed himself to speculate that the philosopher had avoided writing directly about Christianity, as what prevented him from overtly preaching its glory was his Roman patriotism, and from reproving it being his own convictions.

Apart from the above mentioned quotations from De superstitione, Augustine refers twice more to Seneca's words. In book V of De civitate Dei, in opposing those who saw the history-governing force in fate, he quotes, with a reservation that he is not sure who wrote the work, a short poem by Seneca, which actually was one written by Cleanthes and translated by Seneca (Ep. ad Lucil. 107). ${ }^{28}$ Augustine argues that Seneca himself claimed that destination is subordinated to the will of the supreme deity, and that God's knowledge of future events does not preclude the free will of individual humans. Hence, the authority of Seneca, the Stoic, served the bishop of Hippo to undermine the views of those who attributed a special role to the power of fate based on the Stoic doctrine.

The last personal quotation from Seneca's work, unknown to us today, comes from Augustine's Letter 153 (years 412/413) addressed to the governor of Roman Africa, Macedonius. ${ }^{29}$ This letter is a kind of apologia for the activities

septenis interpositos dies septimam fere partem aetatis suae perdant vacando et multa in tempore urgentia non agendo laedantur. Christianos tamen iam tunc Iudaeis inimicissimos in neutram partem commemorare ausus est, ne vel laudaret contra suae patriae veterem consuetudinem, vel reprehenderet contra propriam forsitan voluntatem."

${ }^{28}$ Aug. De civ. V 8: "Annaei Senecae sunt, nisi fallor, hi uersus: duc, summe pater altique dominator poli, / quocumque placuit, nulla parendi mora est."

${ }^{29}$ Aug. Ep. 153,5: "merito ait Seneca, qui temporibus apostolorum fuit, cuius etiam quaedam ad Paulum apostolum leguntur epistulae: omnes odit, qui malos odit." 
of the bishop in intervening with the secular authorities in matters of people convicted by them. It seems that in this case a sententious explicitness of the quoted phrase ("omnes odit, qui malos odit") perfectly matching the matter addressed in the letter, and to a lesser extent Seneca's authority, played a key role in invoking him by Augustine. We are not in a position to identify a proper place in the philosopher's extant writings, from which the quoted words could come. Arguably, the governor himself was a Christian, for Augustine's arguments, which - as results from the extant reply to this letter-were convincing for Macedonius, and were based mainly on the authority of Holy Scripture. This senior Roman official received a good classical education, which Augustine knew perfectly well, because in another letter addressed to him, in referring to the evidence of Cicero's Tusculan Disputations, he did it in such a way as if the location of relevant place in Cicero's letter was obvious for his correspondent. ${ }^{30}$

Even a cursory analysis of these places in the earliest Christian literature which have survived until the present, in which the authors make personal references to Seneca's authority, allows us to formulate more general conclusions. The letters in which those references could be found share two features: they were all written by eminent experts in Roman classical literature, and all were persuasive in nature: apologetic or polemic. Personally identified quotations/references to any of the philosopher's letters are used by Christian writers almost exclusively as an argument in a dispute with well-educated opponents of Christianity, who based their criticism on the philosophical tradition, often the Stoic one. So, Seneca is treated here as an obvious, not to say the most important, philosophical authority in the Latin world. Confirming the validity of the expositions defending Christian theology with his wisdom had a strong argumentative force. Suggestions of Seneca's conscious or unconscious closeness to Christianity were supposed to peculiarly tame this philosophical authority in Christian circles on the one side, and on the other, they made recipients who were well educated and close to Stoicism ponder their own critical attitude to Christianity.

The source material presented here induces one to ask a question to which, for obvious reasons, it is not possible to give a satisfactory answer, but which is related to subsequent reception of Seneca in general. Namely, it is hard to understand why almost none of Seneca's works quoted here by name or by title deserved to survive except in fragments other than those invoked in the works of Christian authors discussed above. These writings include: De superstitione, De immatura morte; Exhortationes, Libri moralis philosophiae, De matrimonio.

${ }^{30}$ Aug. Ep.155,1: “est apud Ciceronem in extrema, ut scis, parte quinti tusculanarum libri locus $[\ldots] . "$ 
Apart from one quotation from De beneficiis and one from the Moral Letters to Lucilius, we are not able to demonstrate another place in the philosopher's works from which other statements of Seneca may come which are invoked by early Christian writers, but with no reference to a specific work. If it's true that the relatively vastly preserved works of Seneca owe their fortunate situation to a particularly favourable treatment by the Christian Middle Ages, then there arises the question of why the authorities of Tertullian, Lactantius, Jerome or finally Augustine were not decisive in the survival of any of the philosopher's writings to which they made personal references?

\section{BIBLIOGRAPHY}

\section{Primary sources}

Ingremeau 2006: Ingremeau, Ch. 2006. "Introduction” In: Lactance. Institutions divines. Livre VI. Introduction, texte critique, traduction, notes et index par Chr. Ingremeau, Sources Chrétiennes 509, Paris.

Waszink, J.H. 1980: Tertullian, Über die Seele, eingel., übersetzt und erläutert von Waszink, J.H. 1980. München.

\section{Secondary sources}

Fredouille 1972: Fredouille, J.-C. 1972. Tertullien et la conversion de la culture antique, Paris. Fürst 2006: Fürst, A. 2006. Der apokryphe Briefwechsel zwischen Seneca und Paulus, Tübingen. Hagendahl 1967: Hagendahl, K.O.H. 1967. Augustine and the Latin Classics, vol. 2, Göteborg. Hunter 2007: Hunter, D.G. 2007. Marriage, Celibacy, and Heresy in Ancient Christianity: The Jovinianist Controversy, Oxford.

Lausberg 1970: Lausberg, M. 1970. Untersuchungen zu Senecas Fragmenten, Berlin 1970.

Lo Cicero 1991: Lo Cicero, C. 1991 "«Omnium stoicorum acutissimus»: Seneca filosofo in Lattanzio: intertestualità e rescrittura," In Studi di filologia classica in onore di Giusto Monaco, vol. III: Letteratura latina dall' età di Tiberio all'età del basso impero, 1237-1261 Palermo.

Monat 1982: Monat, P. 1982. Lactance et la Bible: une propedeutique latine à la lecture de la Bible dans l'Occident constantinien, Paris.

Nehring, P. 2007: Nehring, P. 2007. 'Jovinian, Jerome and Augustine. The Bible in the Service of Arguments,' Palamedes 2:189-200.

Pichon 1902: Pichon, R. 1902. Lactance. Étude sur le mouvement philosophique et religieux sous le règne de Constantin, Paris.

Sider 1971: R.D.S. Sider, 1971. Ancient Rhetoric and the Art of Tertullian, Oxford.

Schofield 1991: Schofield, M. 1991. The Stoic Idea of the City, Cambridge.

Takács 2000: Takács, L. 2000. "Seneca e Girolamo", Aeuum Antiquum 13.

Trillitzsch 1965: Trillitzsch, W. 1965. "Hieronymus und Seneca", Mittellateinisches Jahrbuch 2.

Trillitzsch 1971: Trillitzsch, W. 1971. Seneca im literarischen Urteil der Antike: Darstellung und Sammlung der Zeugnisse. Vol. I, Amsterdam. 


\section{THE AUTHORITY OF SENECA IN THE EARLY CHRISTIAN ARGUMENTATION}

\section{Sum mary}

The analysis of the quotations from the works of this famous Roman philosopher and also some hints to them with a declaration of their authorship leads to the conclusion that his authority in the world of Christian literature went far beyond the sphere of similarities between Stoic and Christian ethics. The early Church authors refer to Seneca almost exclusively in the dispute with the well-educated opponents of Christianity who based their criticism on the philosophical, very often Stoic tradition. Seneca is regarded in the circle of Christian Latin writers as the most important and almost obvious philosophical authority. Quoting his words in support of arguments concerning various theological issues enhanced their position in the debate. 